\title{
Analysis of Community Participation in Managing Sipin Lake, Jambi City
}

\author{
M. Yusuf ${ }^{1}$, Samsuddin $^{2}$, Maiela Yuskha ${ }^{3}$ \\ \{myusuf@unja.ac.id ${ }^{1}$,samsudinmip@gmail.com², yuskhamaiela@gmail.com³ \\ Universitas Jambi, Indonesia \\ Sekolah Tinggi Ilmu Sosial dan Ilmu Politik Nurdin Hamzah, Indonesia ${ }^{2,3}$
}

\begin{abstract}
This study aims to analyze the rise of community participation in the management of Sipin lake. The tourism management will be effective with community involvement, while the lack of participation caused the failure of development; even people resist the government policies. Various literature discusses this issue focus on a normative perspective that considers the community has to be involved. This article relevant to analyze the participation from the bottom perspective, which focuses on the process, actors, and factors. This study uses a qualitative explorative method, the data collected from an interview, observation, and various sources. The result shows that participation in the management of tourism objects rise from the process of taking a role by actors for reasons of economic benefits, concern for environmental and cultural conditions, and response to policies. This study highlights that the rising factor of participation is a response to the planning and policy implementation that not involve non-governmental actors.
\end{abstract}

Keywords: Community Participation, Rise, Sipin Lake, Tourism Management.

\section{Introduction}

Tourism is one of a sectors that can encourage economic growth both on the global and national level. In a global context, tourism is one of the stimulators of socio-economics transformation because of its contribution to national development, poverty reduction, and increased household livelihoods. It notes that tourism contributed more than $10 \%$ of the global gross domestic product (GDP). In Indonesia, within 2018, tourism contributed 19.2 billion USD of foreign exchange. However, tourism in Indonesia has a weakness, such as the poor quality of guides, lack of tourist information, and the development of destination not maximal yet [1]-[4].

This study aims to analyses community participation (CP) in the management of Sipin lake (SL). SL located in the Jambi city managed as a tourist attraction, such as the construction of jogging tracks and the center of micro and medium business. The management of this region face governance problems where under top-down development, while the development paradigm developed into a participatory approach. This study is relevant because community involvement is very fundamental and tourism governance is a challenge in many countries [5][6]. Constitution of the Republic of Indonesia number 10 of 2009 concerning tourism and Constitution of the Republic of Indonesia number 23 of 2014 concerning regional governments also require the involvement of various stakeholders in management [7][8]. 
Several studies discuss participation use a practical or normative and dynamic approach. Those research exposed the importance and necessity of the community to participate in tourism development based on the efficiency of involvement, involvement factors such as the socioeconomic and demographic factors [3][9]-[14]. Community involvement is an evolutionary process involving the exchange of capital among the stakeholders involved [15][16].

Those studies do not provide specific studies on the background of the process, actors, and factor of community involvement in the management of lake tourism objects as an integrated part of ecological aspects and tourism activities. The relevant of this paper is to position participation as a natural process. There is an opportunity to examine the rise of community involvement. Specifically, this paper wants to answer the question of how the process, who the actors, and why they took part in the provision of services in the SL tourist area. At the same time, government institutions did not involve them.

\section{Methods}

This study examines SL management in the Jambi city as a tourist area, and controlled lake fisheries activities support it. The development of SL based on regional regulation number 9 of 2013 on Jambi city spatial plan in 2013-2023 [17] and, then outlined in the Jambi medium-term regional development plan in 2013-2018. The area of \pm 161 ha located in the Telanaipura subdistrict of Jambi city (Figure 1), which functions as a cultural and tourism center and economic resource for the community who lives surround the lake. The development of the SL area began in 2017, beginning with the construction of a pedestrian designed with the concept of a waterfront city (WFC).

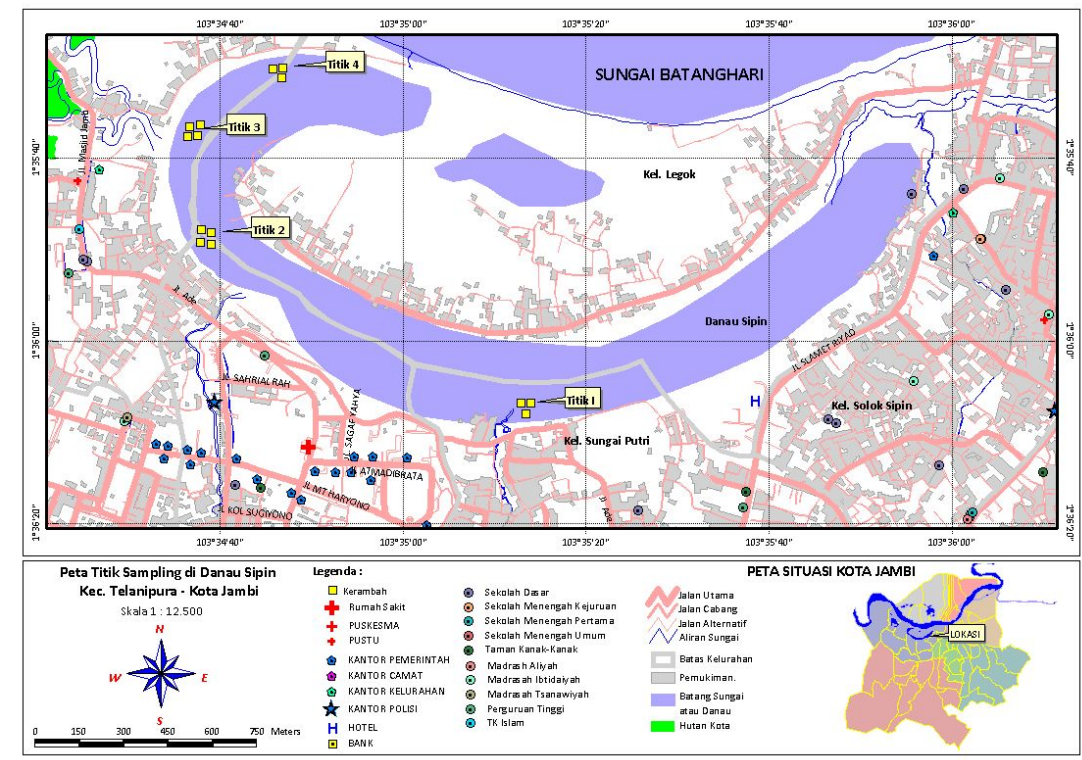

Fig. 1. Map of SL [18]. 
This study uses qualitative explorative to explore the phenomenon of community involvement deeply. The data collected from primary data through interviews mutually with participant observation, where researchers identify the phenomenon [19]. Primary data collected from interviews with informants (Wak Kocai group, boat service provider group, parking management group, fish cultivation group, and merchant group as well as with tourism, parking, and public works agencies). Secondary information collected through tracing the previous study, local regulations, spatial planning documents, news, and relevant supporting data. All data processed by coding techniques to obtain meaning. At the end of the discussion, we conclude, and we give recommendations for academic and practical importance.

\section{Theoretical Framework}

Participation is understood as redistribution of power to the community in public affairs to strengthen democracy and produce more effective governance [20][21]. Participation legitimizes direct, indirect, active, and passive involvement at local, regional, and national levels. Through engagement, public opinion can be obtained to find out their expectations. The community will be more supportive of tourism development if they have the challenge to be involved in the planning and development process to make the community more democratic [14].

In the context of SL tourism management, community participation is seen as a movement of community involvement in the process of providing tourist services to tourists while enjoying the results of the involvement voluntarily or not voluntarily. Social processes to take part (voluntarily) in formal or informal activities, programs or discussions to bring planned changes or improvements in people's lives, services or resources [22].

To analyze the rise of CP in SL management this paper identifies the process, actors and factors (figure 1).

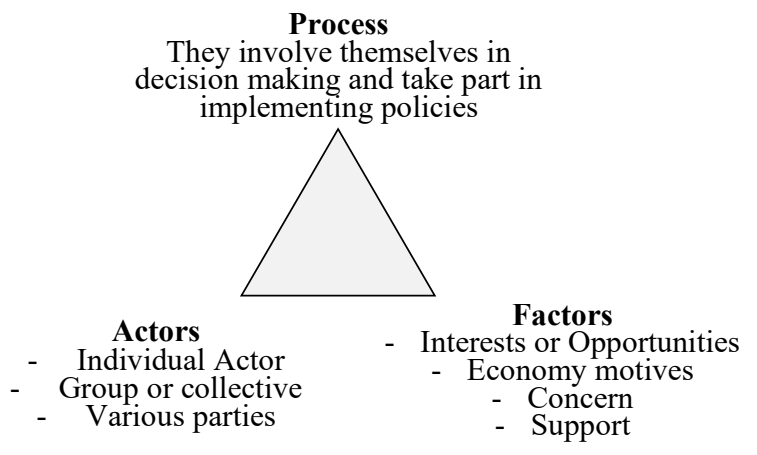

Fig. 2. The rise of participation

\subsection{Participation Process}

The community wants to be involved in making tourism development policies so that policymakers can solve problems and respond to their needs [9], [23]. Participation is a way and opportunity for people who do not have the power to take a role, influence the planning process 
to decision making [20][24]. Tourism activities aim to increase opportunities and reduce social, economic and environmental disparities [25].

\subsection{Participating Actors}

Communities are social actors rather than passive subjects, to make decisions, and to control activities that affect their lives [26]. Tourism management involves various parties and community participation in the process of involving all relevant and interested parties. Such as governments at various levels, residents, architects, developers, business people, and planners in such a way that decision making is shared [25]. Furthermore, there are key actors in the community who are active partners in solution-oriented. Thus, the parties involved in participation can come from various groups who are concerned about specific issues [27].

\subsection{Factors of Participation}

Several factors raise community participation are support (from the government, private or community or family), legitimacy of laws and policies, motivation of participants to get benefits, and wish to protect environment [3][28]. Actors have self-confidence, interest, and the availability of opportunities to take part [13]. Character and morals are factors that influence their participation [11]. The existence of a motivation to obtain benefits or enjoy the results of the engagement process, which is supported by other factors such as environmental care and support, motivate the community to participate.

\section{Findings and Discussion}

\subsection{Development and Community Involvement}

The development of the SL area as an iconic tourist attraction in Jambi city has been one of the main concerns of the mayor of Jambi city since 2013. The development of the lake is a vital area to improve the environment health. Sustainable management will affect both the economic and social conditions of the surrounding communities [29][30].

The development as a tourist attraction as a water-friendly city aims to revive aspects of culture integrated with economic activities. The lake becomes a vital component in the tourism industry in various countries as an ideal destination. Generally, the lake used for various recreational activities. Such as boating, fishing, scuba diving, and water skiing. For this reason, the lake is very prominent in the increasing number of tourists [31].

The management as a tourist area in the community engagement planning process is not an agenda that is considered essential to involve non-governmental actors, likewise, with the regional development process conducted by a top-down approach. While the development paradigm is normatively set out in the law of the Republic of Indonesia, number 10 of 2009 concerning tourism and law number 23 of 2014 concerning local government has emphasized that tourism development must be done in a participatory aptroach. Cazan also suggest the need for $\mathrm{CP}$ in tourism through the decision-making process and the distribution of tourism benefits [24]. 
The emergence of CP in SL management is a response to the area management policy that excludes community involvement. The process of participation can be described as follows (Figure 3):

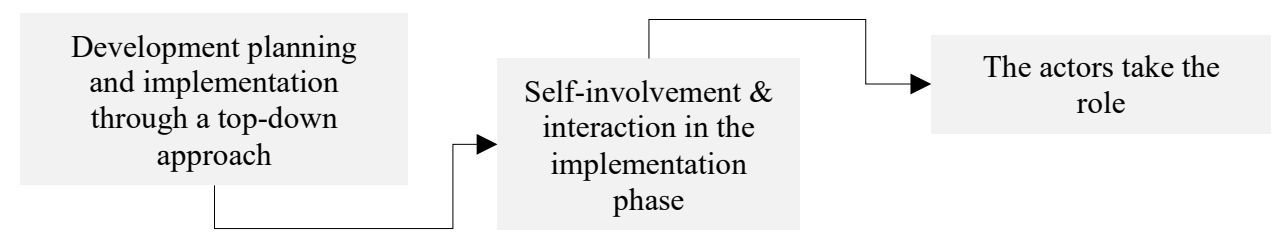

Fig. 3. The process of forming participation

In the process of development, there are obstacles because the public official of Jambi city does not have a master plan for development and management. The new construction conducted in early 2017 , starting with the construction of jogging track (480 meters) from the Jambi city budget of 3.5 billion Rupiahs. Then in 2018 continued with the construction of small and medium micro-business newsstands. So that in practice found various problems such as resistance from the community, overlapping between the provincial government and the city government of Jambi. In this context, the development of the lake area creates a space for the interaction of various parties concerned with the resources.

The SL development is intended as an integrated area between tourism activities and culture to open a struggle for sources of income through tourism service provision activities. The absence of government institutions that regulate $\mathrm{CP}$ patterns is a major factor in the emergence of efforts to take part in the development of attractions. The invitation to participate is expressed in the form of appeals through the media to all Jambi people so as to provide opportunities for those who have the desire.

The parties who have interests try to involve themselves by participating in overseeing the process of development. In the next stage, post-development they take advantage of opportunities to provide tourism services such as boats, water games, photo services, food and parking services. Beneficiaries cause friction between them, and with government agencies. They fight each other to get a strategic place, fish cultivation groups are forced to shift to a place free from water play activities.

The normative approach considers that participation is a necessity for the community to be involved in the policy cycle, tourism development and CP need to be integrated if they want to obtain sustainable benefits [3][9]. In practice, community involvement is neglected with a topdown approach to development, leading to the act of incorporating into the service provider section. In such conditions as well as making them as participants who enjoy the results of the development of the pedestrian path.

\subsection{Participants in the Provision of Tourism Services}

Citizen involvement is very important for a democratic system of government to strengthen and maintain a balanced relationship between citizens and the government [32]. Engagement will give rise to good feedback on contributions to policy formulation to minimize conflict. They participate in formal or voluntary associations because they care about the environment, have motivation, have experience in leadership [22]. 
The SL management provides opportunities for the community to provide services for visitors. Those involved take part in groups and individuals. Their involvement and the role they take is not determined by the government; they take part in each by looking at business opportunities that they consider profitable.

\begin{tabular}{|ll} 
Wak Kocai Community & $\begin{array}{l}\text { Is a community engaged in providing rest areas, photo } \\
\text { spots and photography services, meeting places, concert } \\
\text { venues, food, water boats. }\end{array}$ \\
\hline Parking Management Group & $\begin{array}{l}\text { There are two groups of parking managers, they manage } \\
\text { parking (determine location and set rates). }\end{array}$ \\
\hline Boat service provider group & $\begin{array}{l}\text { Consisting of } 9 \text { people who use small boats, 1 person } \\
\text { using motorized boats. They provide water travel services } \\
\text { around lake. }\end{array}$ \\
\hline Fish culture group & $\begin{array}{l}\text { This group existed before SL was managed for tourism, } \\
\text { its existence being a lake icon. They use the lake as a } \\
\text { place for fish cultivation as a source of income. } \\
\text { They began to get a place at the beginning of the } \\
\text { construction of small and medium micro business kiosks. }\end{array}$ \\
\hline $\begin{array}{l}\text { Micro and Medium business } \\
\text { group }\end{array}$ &
\end{tabular}

Fig. 4. Actors and role (Sources: primary data).

There are consequences that must be faced with this condition, in the pedestrian development process there is an open conflict between the Wak Kocai community and the implementers of development, as well as the construction of small and medium-micro business that give birth to claims to land. We see the actors involved fighting each other to get a strategic area, the impact of fish cultivation groups shifted to another place for reasons of water game tourism. Small businesses from boat service groups fight each other, paddle groups fight with boat service providers that use engines.

\subsection{The Rise of Participants and Motivation}

Community involvement in the management of lake is driven by economic factors, environmental and cultural awareness as well as responses to patterns of decision making and policy implementation carried out without going through public consultation. All these factors reinforce one another (figure 5).

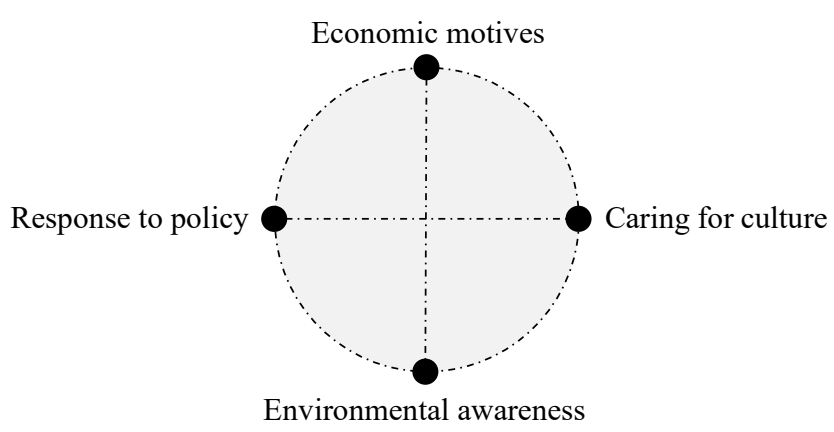

Fig. 5. Factors of participation 
The rise of $\mathrm{CP}$ in the provision of tourism services on the SL is driven by the desire to take advantage of the existence of attractions. The factor of participation in tourism activities was dominated by income factors [13][22]. Involvement has an impact on the economy like this is the type of participation that is preferred, supported also by motivation and ability to contribute [26]. SL is an opportunity as an alternative source of income for people who directly live and use attractions as a business opportunity that is quite promising after the construction of the area as a tourist attraction.

The development of the tourism sector is actually a job and business opportunity as an economic alternative to the local community in addition to primary economic activities [16][33]. Local people realize the potential benefits of tourism are factors that influence them in increasing participation in tourism [28]. But on the other hand there are obstacles to CP in terms of the character of the community quickly bored with something that is routine as well as lack of self-confidence and lack of mobilizers [11].

Local people tend to participate in tourism activities to find solutions to their environmental impacts [12]. The condition of SL environment is one factor that emerges the initiative of the actors involved. The area designated as a tourist area that is supported by controlled fishery activities is faced with a decline in water quality and siltation caused by waste disposal and over-exploitation of the lake. The desire to protect and restore the lake is free from waste. The emergence of participation is more due to the motivation to protect the environment as an integrated part of human life.

The existence of environmental insights will lead to participation, that awareness rises to preserve the environment. Community perceptions of ecotourism quite contribute to the birth of $\mathrm{CP}$ in tourism development [34]. In SL the awareness factor is indeed not a dominant thing, but this is another driving factor besides the economic factor. At the very least, the awareness of environmental issues that are developing in the global, national and city contexts in Jambi contributed to the birth of desire to improve conditions.

Awareness of the existence of SL as ecotourism is supported by the desire to integrate the lake as a tourist attraction with the local wisdom of the local culture. This area is surrounded by residential areas in four urban village (Legok, Buluran Kenali, Sungai Putri and Telanaipura) Telanaipura sub-district. Around the lake there are still traditional Malay house buildings, traditions of using lake water for households, traditions of utilizing lake products (such as lake fish) to meet daily needs and for buying and selling. This region is also packed with folklore through the character 'Cik Upik' who is described as a beautiful woman who sailed from West Sumatra.

In the policy implementation process, there are efforts to involve the community, but in the form of requesting approval for the construction of center of micro and medium bussines. Approval must be obtained because there are community activities in the development area, the area is community land while development must continue. So, the community involved in the center of micro and medium bussines is more because of the results of negotiations with the government, they are given a place to carry out economic activities so that development can continue. Participation that occurs in SL is a form of disappointment with the development process that is top-down, so that it raises an attitude of taking action individually from among the participants. The lack of public consultation in decision making creates a gap between expectations and reality. They did not get information about the actual government agenda [14]. 


\section{Conclusion and Recommendation}

The research objective is to analyze the process, actors, and factors of $\mathrm{CP}$. This study found that the rise of actors from various societies who took part in the provision of services in the SL came from the choices of the community. The local government does not involve nongovernmental stakeholders based on the mandate of the law in the planning up to the implementation stage, but rather the community involves themselves to play a role in development, which have an impact on welfare, for environmental sustainability as an integrated part of cultural revitalization. This research highlights community involvement as a response to top-down planning and decision-making models by avoiding the aspirations of nongovernmental actors.

Based on the conclusion, this paper recommends a management model that provides opportunities for communities to take roles according to their abilities. Community involvement needs forum in the form of specialized units that hold responsibility for lake management. The units need to form to anticipate the possibility of conflicts of interest between individuals or between groups that have a destructive impact. We suggest further research that examines the pattern of participation in lake management involving the community.

Acknowledgement. This paper was funded by the Ministry of Research, Technology, and Higher Education in 2019.

\section{References}

[1] A. Rahajeng, "The role of Kulon Progo regional government in developing nature-based tourism," JKAP (Jurnal Kebijak. dan Adm. Publik), vol. 20, no. 2, pp. 49-62, 2016.

[2] Kompas, "Pariwisata berdaya saing," Kompas, Jakarta, p. 13, Sep-2019.

[3] F. Mugizi, J. Ayorekire, and J. Obua, "Factors that influence local community participation in tourism in Murchison falls conservation area," J. Environ. Sci. Eng., vol. A 6, pp. 209-223, 2017.

[4] J. Mariyono, "Determinants of demand for foreign tourism in Indonesia," J. Ekon. Pembang., vol. 18 , no. 1, pp. 82-92, 2017.

[5] A. Giampiccoli and M. Saayman, "Community-based tourism development model and community participation," African J. Hosp. Tour. Leis., vol. 7, no. 4, pp. 1-27, 2018.

[6] M. W. Islam, L. Ruhanen, and B. W. Ritchie, "Adaptive co-management: a novel approach to tourism destination governance?," J. Hosp. Tour. Manag., vol. xxx, pp. 1-10, 2017.

[7] Indonesia, Constitution of the Republic of Indonesia number 23 of 2014 concerning Regional Government. Indonesia, 2014.

[8] Indonesia, Constitution of the Republic of Indonesia number 10 of 2009 Concerning Tourism. Indonesia, 2009.

[9] R. M. Thetsane, "Local community participation in tourism development: the case of Katse villages in Lesotho," Athens J. Tour., vol. 6, no. 2, pp. 123-140, 2019.

[10] G. F. Hassan, A. El Hefnawi, and M. El Refaie, "Efficiency of participation in planning," Alexandria Eng. J., vol. 50, pp. 203-212, 2011.

[11] M. B. Muwifanindhita and H. Idajati, "Identifikasi faktor yang memengaruhi partisipasi masyarakat kampung Ketandan sebagai kampung wisata di Surabaya," J. Tek. ITS, vol. 7, no. 2, pp. C216-C222, 2018.

[12] H. P. D. Setiyorini, R. Andari, and J. Masunah, "Analysing factors for community participation in tourism development," J. Tour. Hosp. Essentials J., vol. 9, no. 1, pp. 39-44, 2019.

[13] N. H. M. Salleh, M. S. Shukor, R. Othman, M. Samsudin, and S. H. M. Idris, "Factors of local community participation in tourism-related business: case Langkawi island," Int. J. Soc. Sci. 
Humanit., vol. 6, no. 8, pp. 565-571, 2016.

[14] B. K. L. Mak, L. T. O. Cheung, and D. L. H. Hui, "Community participation in the decisionmaking process for sustainable tourism development in rural areas of Hong Kong , China," Sustainability, vol. 9, pp. 1-13, 2017.

[15] H. Xu, F. Jiang, G. Wall, and Y. Wang, "The evolving path of community participation in tourism in China," J. Sustain. Tour., vol. 0, no. 0, pp. 1-20, 2019.

[16] I. M. Adikampana, L. P. K. Pujani, and S. Nugroho, "Partisipasi masyarakat lokal dalam pengembangan kawasan pariwisata Candidasa," J. Kaji. Bali, vol. 08, no. 1, pp. 53-70, 2018.

[17] J. City, Regional Regulation of Jambi City No. 9 of 2013 concerning the spatial and regional planning of the Jambi city in 2013-2023. Indonesia, 2013.

[18] "Peta Danau Sipin-Kota Jambi.".

[19] P. Corbetta, Social research: theory, methods and techniques. London, Thousand Oaks \& New Delhi: SAGE Publications, 2003.

[20] A. Shani and A. Pizam, "Community participation in tourism planning and development," in Handbook of tourism and quality of life research: enhancing the lives of tourists and residents of host communities, international handbooks of quality of ife, M. Uysal, Ed. Springer Science+Business Media B.V, 2012, pp. 547-564.

[21] S. R. Arnstein, "A ladder of citizen participation," J. Am. Plan. Assoc., vol. 35, no. 4, pp. 216 224, 1969.

[22] N. Bracht and A. Tsouros, "Principles and strategies of effective community participation," Health Promot. Int., vol. 5, no. 3, pp. 199-208, 1990.

[23] S. B. Rifkin, F. Muller, and W. Bichmann, "Primary health care: on measuring participation," Soc. Sci. Med., vol. 26, no. 9, pp. 931-940, 1988.

[24] I.-C. Cazan, "Community participation in tourism destination development: a literature review," in The 14th Economic International Conference: Strategies and Development Policies of Territories: International, Country, Region, City, Location Challenges, 2018, pp. 219-228.

[25] K. M. Haywood, "Responsible and responsive tourism planning in the community," Tuorism Manag., vol. 9, no. 2, pp. 105-118, 1988.

[26] S. M. Rasoolimanesh and M. Jaafar, "Community participation toward tourism development and conservation program in rural world heritage sites," in Tourism - from empirical research towards practical application, L. Butowski, Ed. London: IntechOpen, 2016, pp. 1-14.

[27] S. Aboelnaga, "Public participation in planning in the Egyptian contex," Challenges Mod. Technol., vol. 8, no. 2, pp. 31-36, 2017.

[28] R. M. Ziku, "Partisipasi masyarakat desa Komodo dalam pengembangan ekowisata di pulau Komodo," Jumpa, vol. 2, no. 1, pp. 1-21, 2015.

[29] B. K. Laras, Marimin, I. W. Nurjaya, and S. Budiharsono, "Desain kebijakan pengelolaan kota tepian pantai: kasus kota Semarang," Forum Pascasarj., vol. 34, no. 4, pp. 231-248, 2011.

[30] D. Vollmer, "Urban waterfront rehabilitation: can it contribute to environmental improvements in the developing world?," Environ. Res. Lett., vol. 4, no. 2, pp. 1-7, 2009.

[31] T. W. Heggie, "Lake tourism fatalities: a 46-year history of death at Lake Powell," J. Travel Med., pp. 1-5, 2018.

[32] T. Molokwane and L. M. Tshombe, "Citizen involvement in the formulation of public policy," in The 3rd Annual International Conference on Public Administration and Development Alternatives 04 - 06 July 2018, 2018, no. July, pp. 192-199.

[33] C. Seftyono, "Local Community in Valuing Ecosystem Services: Warga Kampung Code's Perspective on Kali Code Existence," in Proceeding 1st Annual Indonesian Scholars Conference in Taiwan, 2010, vol., no., p. .

[34] S. Hayati, "Partisipasi masyarakat dalam pengembangan ekowisata di Pangandaran-Jawa Barat," Forum Geogr., vol. 24, no. 1, pp. 12-27, 2010. 